\title{
Indium Recovery from Waste Liquid Crystal Display via Chloride Volatilization Process: Thermodynamic Computation
}

\author{
Yaoguang Guo, ${ }^{1}$ Qichao Zhang, ${ }^{1}$ Xiaoyi Lou, ${ }^{2}$ Huili Liu, ${ }^{1}$ Jiangbin Wang, ${ }^{1}$ Jie Guan, ${ }^{1,3 *}$ Xin Xu, ${ }^{4}$ Xiaojiao
} Zhang, ${ }^{1}$ Yaguang Li, ${ }^{4}$ Yingshun $\mathrm{Li}^{,},{ }^{5}$ and Zhanhu Guo ${ }^{6^{*}}$

With the increase of the scrap liquid crystal displays (LCDs), recycling indium from waste LCDs has captured an international attention. Chloride metallurgy is a promising method for indium recovery from LCD panels, due to the lower boiling point of indium chloride. In the present study, thermodynamic analyses of indium recovery from waste LCDs via chloride volatilization process by the HSC Chemistry software was carried out to understand the reaction mechanism between chlorinating agent and LCDs to avoid adverse factors, and simultaneously obtain the optimal conditions for the extraction of indium. The results show that the recovered indium from LCDs with $\mathrm{HCl}$ as the chlorinating agent from the PVC pyrolysis is feasible, with the chlorination temperature controlled between 134.49 and $554.25^{\circ} \mathrm{C}$, and the evaporation temperature higher than $490{ }^{\circ} \mathrm{C}$, and simultaneously, the oxygen partial pressure controlled or under anaerobic conditions. As such, the influences of $\mathrm{SiO}_{2}, \mathrm{Al}_{2} \mathrm{O}_{3}$ and $\mathrm{Fe}_{2} \mathrm{O}_{3}$, contained in LCDs, can be ignored or avoided, and only $\mathrm{CaO}, \mathrm{K}_{2} \mathrm{O}$ and $\mathrm{Na}_{2} \mathrm{O}$ would consume partial pressure of $\mathrm{HCl}$ gas, reducing the indium recovery reaction rate. The present study might provide important inspiration for indium recovery from waste LCDs via chloride volatilization process.

Keywords: Chloridizing metallurgy; Thermodynamics; Indium chloride

Received 26 June 2018, Accepted 25 August 2018

DOI: $10.30919 / \mathrm{es} 8 \mathrm{~d} 752$

\section{Introduction}

Cathode ray tube (CRT) displays has been replaced by liquid crystal displays (LCDs) in most of appliances, such as televisions, computers, smart phones, eBook readers, etc., owing to the advantages of micron radiation, small volume, light quality, low power consumption, and multi-information display. ${ }^{1}$ As such, a large number of LCDs would be made obsolete worldwide with the updating of these devices with a 3-5 years lifespan., ${ }^{2,3}$ Therefore, the recovery of the waste LCD panels has become an important subject in the field of waste electrical and electronic equipment (WEEE) in recent decades. ${ }^{4}$ Indium (In) is an irreplaceable element in indium-tin oxide (ITO) coating on LCDs with the indispensable characteristics

${ }^{1}$ Research Center of Resource Recycling Science and Engineering, School of Environmental and Materials Engineering, Shanghai Polytechnic University, Shanghai 201209, China

${ }^{2}$ Key Laboratory of Control of Quality and Safety for Aquatic Products, Ministry of Agriculture, East China Sea Fisheries Research Institute, Chinese Academy of Fishery Sciences, Shanghai, 200090, China

${ }^{3}$ Shanghai Pudong Shuguang Research Center for High Environmental Treatment Technologies, Shanghai 20209, China

${ }^{4}$ Shanghai Waigaoqiao Free Trade Zone Environmental Services Co.,Ltd., Shanghai, 200131, China

${ }^{5}$ Shanghai Xin Jinqiao Environmental Protection Co., Ltd., Shanghai 201201, China

${ }^{6}$ Integrated Composites Laboratory (ICL), Department of Chemical \& Bimolecular Engineering, University of Tennessee, Knoxville, TN 37996, USA

*E-mail: guanjie@sspu.edu.cn (J. Guan); zguo10@utk.edu (Z. Guo) of transparency to visible light and excellent electric conduction. ${ }^{2,5}$ It was estimated that $55 \%$ to $85 \%$ of global indium consumption was utilized as ITO films. ${ }^{2,6}$ Indium is a rare element present only in a few natural minerals and with low concentrations in some sulphide ores of zinc, copper and lead. ${ }^{7}$ Generally, indium is obtained from zinc minerals, the content of which varies from 10 to $20 \mathrm{ppm}$, while approximately $84 \%$ of the worldwide consumption of indium is used for the production of LCDs. ${ }^{8}$ Due to the rising demands and rarity present only in a few natural minerals, it is very difficult and expensive for the extraction of indium from natural minerals. As such, the shortage of indium and rising prices are triggered for the future. ${ }^{9,10}$ To prevent the shortage of indium and facilitate sustainable development of related industries, indium recycling from waste LCDs by means of efficient approaches is an urgent necessity.

Many efforts for the recovery of indium have been reported in recent decades. Acid leaching, electroetching and chloride metallurgy are included in the mentioned methods, in which acid leaching is widely used in indium recycling processes. ${ }^{8-18}$ For acid leaching process, indium and tin could be dissolved into acid solution for further recovery of indium. However, a large number of corrosive and volatile acids would be used in the acid leaching process, increasing the operating risk of workers and also generating wasted acid to lead to secondary pollution. Compared with the acid leaching, electroetching technology was applied to remove the ITO film from LCD panels highly energy efficiently and environmental beneficially. ${ }^{11,12,16}$ Nevertheless, intensive energy inputs and high costs restrict LCD panels for electroetching pilot-scale application. In comparison, chloride metallurgy is a promising reported method for indium recovery from LCD panels. ${ }^{15}$ Chlorinated indium can be evaporated at a relatively low temperature and condensed in a cooler 
zone, and indium chloride can be selectively recovered. Furthermore, this process is suitable for industrial large-scale application with lower costs. Ma et al. reported that the recovery of indium from LCD panel reached $98.02 \%$ in a rough vacuum condition via chloridizing metallurgy process with $\mathrm{HCl}$ as chlorinating agent provided by the pyrogenic decomposition of $\mathrm{NH}_{4} \mathrm{Cl} .{ }^{13}$ However, this vacuum condition is difficult to control.

With good performance and low price, polyvinyl chloride (PVC) can be one of the biggest plastic products. The consumption of PVC was around 39.3 million tons in 2013 worldwide. ${ }^{19}$ As such, there will be lots of waste PVC products every year. The GC-MS and material balance analysis after pyrolysis of $\mathrm{PVC}$ show that $\mathrm{HCl}$ was the major product (53\% of the polymer). ${ }^{14}$ The waste PVC might be regarded as a promising precursor of $\mathrm{HCl}$ as the chlorinating agent to recover indium from waste LCD panel, which might achieve the valuable metal indium recovery by the process of "using waste control waste". Park et al. reported that the recovery of indium form LCD powders could reach only $66.7 \%$ with $\mathrm{HCl}$ as the chlorinating agent from the pyrolysis of PVC. ${ }^{8}$ However, Guan et al. examined the extraction of indium by chloridizing metallurgy process with hydrogen chloride produced by PVC pyrolysis to serve as a chlorination agent from LCD powder pretreated with sodium hydroxide solution to remove silicon and aluminum, and the recovery ratio of indium reached as high as $97.50 \%{ }^{20}$ The total content of indium oxide in LCD powders is about $0.05 \%$, while other oxides, especially silica and alumina oxides is much more than $80 \%$ (Table 1), which might have the influence on the recovery of indium. ${ }^{20,21}$

Table 1. The contents of the waste LCD powders.

\begin{tabular}{lcccccccc}
\hline Metal oxide & $\mathrm{In}_{2} \mathrm{O}_{3}$ & $\mathrm{Al}_{2} \mathrm{O}_{3}$ & $\mathrm{SiO}_{2}$ & $\mathrm{Fe}_{2} \mathrm{O}_{3}$ & $\mathrm{CaO}$ & $\mathrm{K}_{2} \mathrm{O}$ & $\mathrm{Na}_{2} \mathrm{O}$ & Others \\
\hline Content (\%) & 0.05 & 14.33 & 66.91 & 0.92 & 4.27 & 0.03 & 0.15 & 13.34 \\
\hline
\end{tabular}

Hence, thermodynamic computation of indium recovery from wasted LCDs via chloride volatilization process was explored to further understand the reaction mechanism between chlorinating agent and LCDs to obtain the optimal conditions for the extraction of indium by chloridizing metallurgy process. The main contents of LCDs, such as $\mathrm{SiO}_{2}, \mathrm{Al}_{2} \mathrm{O}_{3}, \mathrm{CaO}, \mathrm{Na}_{2} \mathrm{O}, \mathrm{In}_{2} \mathrm{O}_{3}, \mathrm{~K}_{2} \mathrm{O}$, etc., were chosen to examine. The present study might provide the theoretical basis for indium extraction from LCDs using chlorine metallurgy method.

\section{Thermodynamic Computation}

Thermodynamic calculations of chlorination reactions between the main chemical constituent, such as $\mathrm{SiO}_{2}, \mathrm{Al}_{2} \mathrm{O}_{3}, \mathrm{CaO}, \mathrm{Na}_{2} \mathrm{O}, \mathrm{In}_{2} \mathrm{O}_{3}$, $\mathrm{K}_{2} \mathrm{O}, \mathrm{Fe}_{2} \mathrm{O}_{3}$, etc., and $\mathrm{HCl}$ were carried out at atmospheric pressure by the HSC Chemistry (Version 5.0 software), a chemical reaction and equilibrium software with an extensive thermochemical database.

\section{Results and discussion}

\subsection{Thermodynamics of $\operatorname{In}_{2} \mathrm{O}_{3}$-HCl system}

The essence of indium recovery from LCD powders via PVC pyrolysis is the chlorination reaction between $\mathrm{HCl}$ and $\mathrm{In}_{2} \mathrm{O}_{3}$. Therefore, it is necessary to study the thermodynamics of $\operatorname{In}_{2} \mathrm{O}_{3}-\mathrm{HCl}$ system at different chlorination temperature. The possible reactions are as follows (Eqs.1-7).

$$
\begin{aligned}
& \mathrm{In}_{2} \mathrm{O}_{3}+6 \mathrm{HCl}=2 \mathrm{InCl}_{3}+3 \mathrm{H}_{2} \mathrm{O} \\
& \mathrm{In}_{2} \mathrm{O}_{3}+2 \mathrm{HCl}=2 \mathrm{InCl}+\mathrm{H}_{2} \mathrm{O}+\mathrm{O}_{2} \\
& 2 \mathrm{In}_{2} \mathrm{O}_{3}+8 \mathrm{HCl}=4 \mathrm{InCl}_{2}+4 \mathrm{H}_{2} \mathrm{O}+\mathrm{O}_{2} \\
& \mathrm{InCl}_{3}=\mathrm{InCl}+\mathrm{Cl}_{2} \\
& 4 \mathrm{InCl}_{3}+3 \mathrm{O}_{2}=2 \mathrm{In}_{2} \mathrm{O}_{3}+6 \mathrm{Cl}_{2} \\
& 2 \mathrm{InCl}_{3}+\mathrm{O}_{2}=2 \mathrm{InO} \mathrm{ICCl} \mathrm{Cl}_{2} \\
& 4 \mathrm{InCl}_{3}+\mathrm{O}_{2}=2 \mathrm{In}_{2} \mathrm{O}+6 \mathrm{Cl}_{2}
\end{aligned}
$$

The present study focus on the thermochemical analysis below $1000{ }^{\circ} \mathrm{C}$ because that the temperature of indium recovery via chloride volatilization is less than $1000{ }^{\circ} \mathrm{C}$ in general. The relationship between Gibbes free energy change and temperature corresponding to abovementioned reaction formulae were shown in Fig. 1 that Eq. 1 is the main route of indium recovery via chloride volatilization, which could occur spontaneously when temperature is lower than $578.11^{\circ} \mathrm{C}$, while Eq. 5 could occur spontaneously when temperature is higher than $554.25{ }^{\circ} \mathrm{C}$. As such, the target product $\mathrm{InCl}_{3}$ would react with oxygen to produce $\operatorname{In}_{2} \mathrm{O}_{3}$ and $\mathrm{Cl}_{2}$, reducing the yield of $\mathrm{InCl}_{3}$. In contrast, other reactions under the same condition could not occur spontaneously as a result of the Gibbes free energy change is greater than 0 . Therefore, better control of reaction temperature is a key point to produce optimal target products, i.e. optimal indium recovery via chloride volatilization process at atmosphere pressure. As for the present chloride volatilization process, the optimal chlorination temperature should be controlled lower than $554.25{ }^{\circ} \mathrm{C}$, and simultaneously, the oxygen partial pressure should be controlled or the process must be controlled under anaerobic conditions.

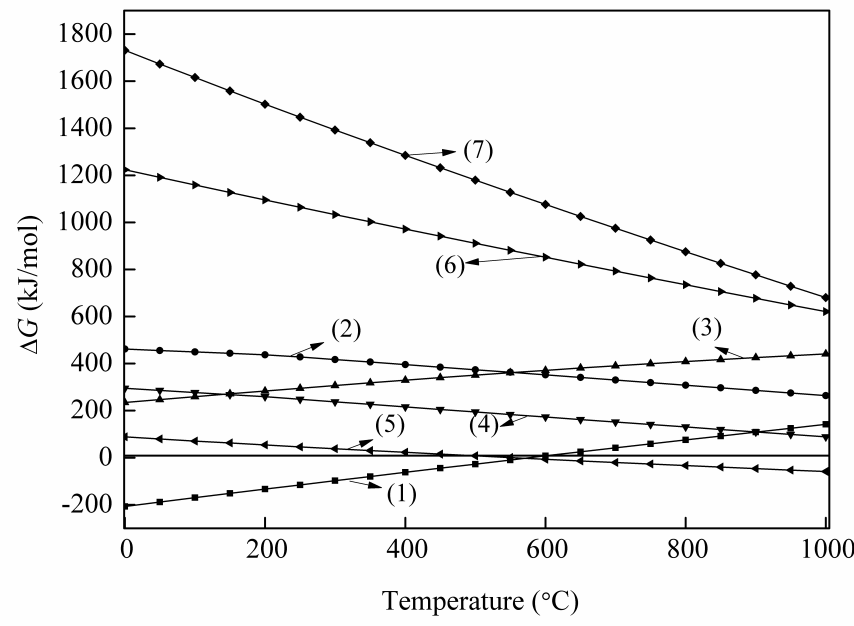

Fig. 1 Graph of relation between $\triangle \mathrm{G}$ and temperature of the reactions in $\mathrm{In}_{2} \mathrm{O}_{3}-\mathrm{HCl}$ system at atmospheric pressure.

\subsection{Thermodynamics of $\mathrm{Al}_{2} \mathrm{O}_{3}-\mathrm{HCl}$ system}

The content of $\mathrm{Al}_{2} \mathrm{O}_{3}$ in the LCD is $14.33 \%$, much higher than that of $\mathrm{In}_{2} \mathrm{O}_{3}{ }^{20,}{ }^{21}$ Therefore, it is necessary to examine the thermodynamics of $\mathrm{Al}_{2} \mathrm{O}_{3}-\mathrm{HCl}$ system to acquire the influence on indium recovery via chloride volatilization process. The possible reactions in $\mathrm{Al}_{2} \mathrm{O}_{3}-\mathrm{HCl}$ system are as follows (Eqs. 8-14). 


$$
\begin{aligned}
& \mathrm{Al}_{2} \mathrm{O}_{3}+6 \mathrm{HCl}=2 \mathrm{AlCl}_{3}+3 \mathrm{H}_{2} \mathrm{O} \\
& 2 \mathrm{Al}_{2} \mathrm{O}_{3}+8 \mathrm{HCl}=4 \mathrm{AlCl}_{2}+4 \mathrm{H}_{2} \mathrm{O}+\mathrm{O}_{2} \\
& \mathrm{Al}_{2} \mathrm{O}_{3}+2 \mathrm{HCl}=2 \mathrm{AlCl}+\mathrm{H}_{2} \mathrm{O}+\mathrm{O}_{2} \\
& 3 \mathrm{AlCl}=2 \mathrm{Al}+\mathrm{AlCl}_{3} \\
& \mathrm{AlCl}+\mathrm{O}_{2}=\mathrm{Al}_{2} \mathrm{O}_{3}+\mathrm{Cl}_{2} \\
& 4 \mathrm{AlCl}_{2}+3 \mathrm{O}_{2}=2 \mathrm{Al}_{2} \mathrm{O}_{3}+4 \mathrm{Cl}_{2} \\
& 4 \mathrm{AlCl}+3 \mathrm{O}_{2}=2 \mathrm{Al}_{2} \mathrm{O}_{3}+2 \mathrm{Cl}_{2}
\end{aligned}
$$

The variation of Gibbes free energy change with the change of temperature for each possible reaction in $\mathrm{Al}_{2} \mathrm{O}_{3}-\mathrm{HCl}$ system at atmospheric pressure is shown in Fig. 2. The results show when the temperature is below $1000{ }^{\circ} \mathrm{C}$, the Gibbes free energy change of the Eqs. 8,9 and 10 is positive so that they could not occur spontaneously, even if the Eqs. 11, 12, 13 and 14 could occur spontaneously at the temperature of indium recovery process. In principle, Eqs. 11, 12, 13 and 14 could not occur spontaneously, owing that Eqs. $8 \& 9$ and 10 cannot occur, namely, $\mathrm{Al}_{2} \mathrm{O}_{3}-\mathrm{HCl}$ system would not produce impurities to have effect on indium recovery via chloride process at the condition of atmospheric pressure and chlorination temperature below $1000{ }^{\circ} \mathrm{C}$.

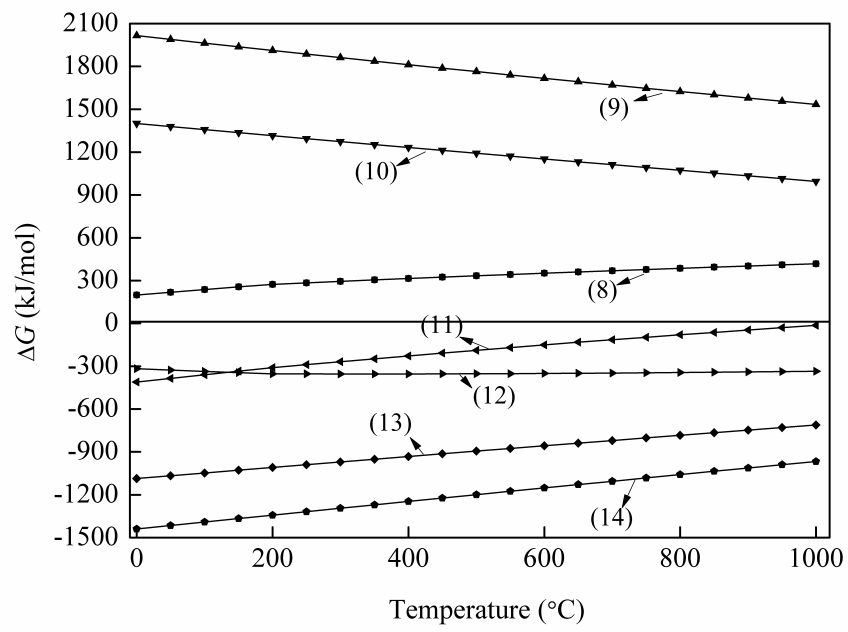

Fig. 2 Graph of relation between $\triangle \mathrm{G}$ and temperature of the reactions in $\mathrm{Al}_{2} \mathrm{O}_{3}-\mathrm{HCl}$ system at atmospheric pressure.

\subsection{Thermodynamics of $\mathrm{Fe}_{2} \mathbf{O}_{3}-\mathrm{SiO}_{2}-\mathrm{HCl}$ system}

The contents of $\mathrm{SiO}_{2}$ and $\mathrm{Fe}_{2} \mathrm{O}_{3}$ in the LCD are $66.91 \%$ and $0.92 \%$, respectively, which are far more than that of $\operatorname{In}_{2} \mathrm{O}_{3} \cdot{ }^{20,21}$ It is necessary to study the thermodynamics of $\mathrm{Fe}_{2} \mathrm{O}_{3}-\mathrm{SiO}_{2}-\mathrm{HCl}$ system in order to examine the influence on the indium recovery. The relative reactions in $\mathrm{Fe}_{2} \mathrm{O}_{3}-\mathrm{SiO}_{2}-\mathrm{HCl}$ system are as follows (Eqs. 15-21).

$$
\begin{aligned}
& \mathrm{SiO}_{2}+4 \mathrm{HCl}=\mathrm{SiCl}_{4}+2 \mathrm{H}_{2} \mathrm{O} \\
& \mathrm{Fe}_{2} \mathrm{O}_{3}+6 \mathrm{HCl}=2 \mathrm{FeCl}_{3}+3 \mathrm{H}_{2} \mathrm{O} \\
& 2 \mathrm{Fe}_{2} \mathrm{O}_{3}+8 \mathrm{HCl}=4 \mathrm{FeCl}_{2}+4 \mathrm{H}_{2} \mathrm{O}+\mathrm{O}_{2}
\end{aligned}
$$

$$
\begin{aligned}
& \mathrm{SiCl}_{4}+\mathrm{O}_{2}=\mathrm{SiO}_{2}+2 \mathrm{Cl}_{2} \\
& 6 \mathrm{FeCl}_{3}+4 \mathrm{O}_{2}=2 \mathrm{Fe}_{3} \mathrm{O}_{4}+9 \mathrm{Cl}_{2} \\
& 4 \mathrm{FeCl}_{3}+3 \mathrm{O}_{2}=2 \mathrm{Fe}_{2} \mathrm{O}_{3}+6 \mathrm{Cl}_{2} \\
& 3 \mathrm{FeCl}_{2}+2 \mathrm{O}_{2}=\mathrm{Fe}_{3} \mathrm{O}_{4}+3 \mathrm{Cl}_{2}
\end{aligned}
$$

Then $\triangle G$-Temperature relation curve of each possible reaction in $\mathrm{Fe}_{2} \mathrm{O}_{3}-\mathrm{SiO}_{2}-\mathrm{HCl}$ system is shown in Fig. 3. The results show that when temperature is lower than $134.49{ }^{\circ} \mathrm{C}$ in the condition of atmospheric pressure, Eq. 16 could occur spontaneously, namely, ferric oxide could react with hydrogen chloride to produce ferric chloride. However, the Gibbes free energy change of Eqs. 19, 20 and 21 is less than zero in the same condition. That is to say Eqs. 19, 20 and 21 can occur spontaneously, i.e., the ferric chloride could be oxidized as iron oxide ultimately. In comparison, the existence of $\mathrm{SiO}_{2}$ hardly affect the recovery of indium, because that Eq. 15 could not occur spontaneously, even if Gibbes free energy change of Eq. 18 is less than zero, i.e., Eq. 18 could occur spontaneously. In brief, the $\mathrm{Fe}_{2} \mathrm{O}_{3}-\mathrm{SiO}_{2}-\mathrm{HCl}$ system has less influence on the main reaction (Eq. 1) of the recovery of indium, even though ferric oxide can react with hydrogen chloride to generate ferric chloride, and followed oxidized to be iron oxide again. So long as the oxygen partial pressure was controlled properly, or the reaction temperature was adjusted to over $134.49{ }^{\circ} \mathrm{C}$, the influence of $\mathrm{Fe}_{2} \mathrm{O}_{3}$ can be avoided.

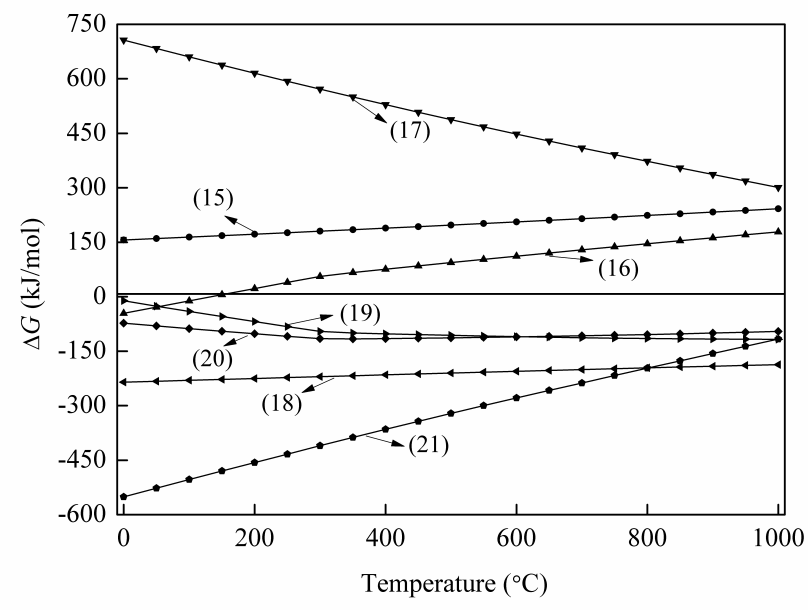

Fig. 3 Graph of relation between $\triangle \mathrm{G}$ and temperature of the reactions in $\mathrm{Fe}_{2} \mathrm{O}_{3}-\mathrm{SiO}_{2}-\mathrm{HCl}$ system at atmospheric pressure.

\subsection{Thermodynamics of $\mathrm{CaO}-\mathrm{K}_{2} \mathrm{O}-\mathrm{Na}_{2} \mathrm{O}-\mathrm{HCl}$ system}

The contents of $\mathrm{CaO}, \mathrm{Na}_{2} \mathrm{O}$ and $\mathrm{K}_{2} \mathrm{O}$ in the $\mathrm{LCD}$ are $4.27 \%, 0.15 \%$ and $0.03 \%$, respectively. ${ }^{20,21}$ Although the content of $\mathrm{K}_{2} \mathrm{O}$ is lower than that of $\operatorname{In}_{2} \mathrm{O}_{3}$, it might compete with $\operatorname{In}_{2} \mathrm{O}_{3}$ to consume $\mathrm{HCl}$, and thus reduce the reaction rate of the indium recovery via chloride volatilization, if the reaction between $\mathrm{K}_{2} \mathrm{O}$ and $\mathrm{HCl}$ is faster than that of $\mathrm{In}_{2} \mathrm{O}_{3}$ and $\mathrm{HCl}$ at the chlorination temperature. Furthermore, all of these three chloride products, i.e. $\mathrm{CaCl}_{2}, \mathrm{NaCl}$ and $\mathrm{KCl}$, can also be used as chlorinating agent. Therefore, it is necessary to study the effect of the $\mathrm{CaO}-\mathrm{K}_{2} \mathrm{O}-\mathrm{Na}_{2} \mathrm{O}-\mathrm{HCl}$ system on the main reaction Eq.1. The possible reactions of $\mathrm{CaO}-\mathrm{K}_{2} \mathrm{O}-\mathrm{Na}_{2} \mathrm{O}-\mathrm{HCl}$ system are as follows (Eqs. 22-36). 


$$
\begin{aligned}
& \mathrm{CaO}+2 \mathrm{HCl}=\mathrm{CaCl}_{2}+\mathrm{H}_{2} \mathrm{O} \\
& \mathrm{K}_{2} \mathrm{O}+2 \mathrm{HCl}=2 \mathrm{KCl}+\mathrm{H}_{2} \mathrm{O} \\
& \mathrm{Na} \mathrm{O}+2 \mathrm{HCl}=2 \mathrm{NaCl}+\mathrm{H}_{2} \mathrm{O} \\
& 3 \mathrm{CaCl}_{2}+\mathrm{In}_{2} \mathrm{O}_{3}=2 \mathrm{InCl}_{3}+3 \mathrm{CaO} \\
& 3 \mathrm{CaCl}_{2}+\mathrm{Al}_{2} \mathrm{O}_{3}=2 \mathrm{AlCl}_{3}+3 \mathrm{CaO} \\
& 2 \mathrm{CaCl}_{2}+\mathrm{SiO}_{2}=\mathrm{SiCl}_{4}+2 \mathrm{CaO} \\
& 3 \mathrm{CaCl}_{2}+\mathrm{Fe}_{2} \mathrm{O}_{3}=2 \mathrm{FeCl}_{3}+3 \mathrm{CaO} \\
& 6 \mathrm{KCl}+\mathrm{In}_{2} \mathrm{O}_{3}=2 \mathrm{InCl}_{3}+3 \mathrm{~K}_{2} \mathrm{O} \\
& 6 \mathrm{KCl}+\mathrm{Al}_{2} \mathrm{O}_{3}=2 \mathrm{AlCl}_{3}+3 \mathrm{~K}_{2} \mathrm{O} \\
& 4 \mathrm{KCl}+\mathrm{SiO}_{2}=\mathrm{SiCl}_{4}+2 \mathrm{~K}_{2} \mathrm{O} \\
& 6 \mathrm{KCl}+\mathrm{Fe}_{2} \mathrm{O}_{3}=2 \mathrm{FeCl}_{3}+3 \mathrm{~K}_{2} \mathrm{O} \\
& 6 \mathrm{NaCl}+\mathrm{In}_{2} \mathrm{O}_{3}=2 \mathrm{InCl}_{3}+3 \mathrm{Na}_{2} \mathrm{O} \\
& 6 \mathrm{NaCl}+\mathrm{Al}_{2} \mathrm{O}_{3}=2 \mathrm{AlCl}_{3}+3 \mathrm{Na}_{2} \mathrm{O} \\
& 4 \mathrm{NaCl}+\mathrm{SiO}_{2}=\mathrm{SiCl}_{4}+2 \mathrm{Na}_{2} \mathrm{O} \\
& 6 \mathrm{NaCl}+\mathrm{Fe}_{2} \mathrm{O}_{3}=2 \mathrm{FeCl}_{3}+3 \mathrm{Na}_{2} \mathrm{O}
\end{aligned}
$$

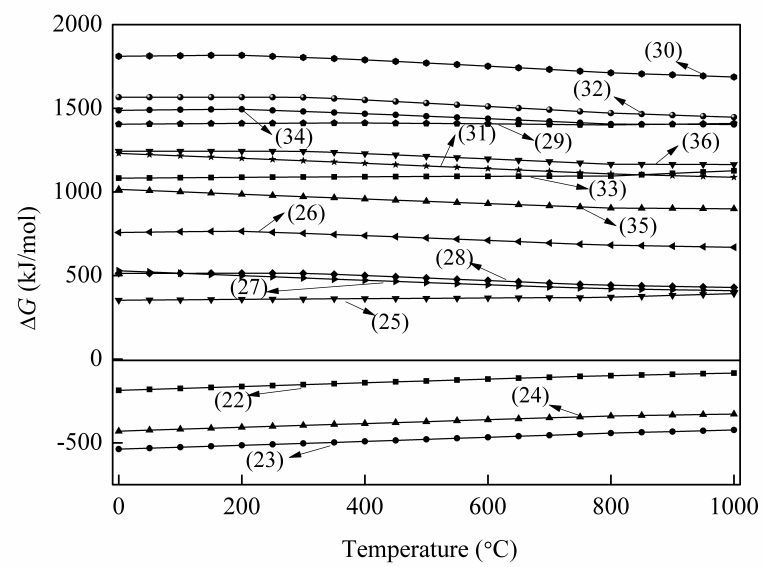

Fig. 4 Graph of relation between $\triangle \mathrm{G}$ and temperature of the reactions in $\mathrm{CaO}-\mathrm{K}_{2} \mathrm{O}-\mathrm{Na}_{2} \mathrm{O}-\mathrm{HCl}$ system at atmospheric pressure.

The variation of Gibbes free energy change of each possible reaction with the temperature changes in $\mathrm{CaO}-\mathrm{K}_{2} \mathrm{O}-\mathrm{Na}_{2} \mathrm{O}-\mathrm{HCl}$ system is shown in Fig. 4. It reveals that Eqs. 22, 23 and 24 could occur spontaneously with the chloride temperature below $1000{ }^{\circ} \mathrm{C}$ at atmospheric pressure, which indicates that $\mathrm{CaO}, \mathrm{K}_{2} \mathrm{O}$ and $\mathrm{Na}_{2} \mathrm{O}$ contained in LCD could consume part of hydrogen chloride to generates these three chlorides. In other words, the partial pressure of hydrogen chloride was reduced in the initial chlorination reaction, resulting in the reduction of chloride rate of the main reaction Eq.1. Unfortunately, the formed chlorinating agents, i.e. $\mathrm{CaCl}_{2}, \mathrm{KCl}$ and $\mathrm{NaCl}$, could not react with $\operatorname{In}_{2} \mathrm{O}_{3}$ in LCD to extract indium with the chlorination temperature lower than $1000^{\circ} \mathrm{C}$ at atmospheric pressure (Eqs. 25, 29 and 33; Fig. 4). However, the formed $\mathrm{CaCl}_{2}, \mathrm{KCl}$ and $\mathrm{NaCl}$ could not evaporate to affect the purity of recyclable indium chloride (Eqs. 37-41; Fig. 5). Therefore, the existence of $\mathrm{CaO}, \mathrm{K}_{2} \mathrm{O}$ and $\mathrm{Na}_{2} \mathrm{O}$ contained in LCD would consume partial pressure of $\mathrm{HCl}$ gas from PVC pyrolysis, reducing the reaction rate of the indium extraction reaction (Eq.1).

$$
\begin{aligned}
& 2 \mathrm{InCl}_{3}=\mathrm{In}_{2} \mathrm{Cl}_{6} \\
& \mathrm{InCl}_{3}=\mathrm{InCl}_{3}(\mathrm{~g}) \\
& \mathrm{CaCl}_{2}=\mathrm{CaCl}_{2}(\mathrm{~g}) \\
& \mathrm{KCl}=\mathrm{KCL}(\mathrm{g}) \\
& \mathrm{NaCl}=\mathrm{NaCl}(\mathrm{g})
\end{aligned}
$$

It was shown in Fig. 5 that Eqs. 37 and 38 can be spontaneous when evaporation temperature higher than $490{ }^{\circ} \mathrm{C}$ and $584.8{ }^{\circ} \mathrm{C}$, respectively, while the side reactions Eqs.39-41 cannot occur spontaneously with the chlorination temperature below $1000^{\circ} \mathrm{C}$ at atmospheric pressure, indicating that selective evaporation of indium chloride can be achieved based on the differences of saturated vapor pressure of different chlorides.

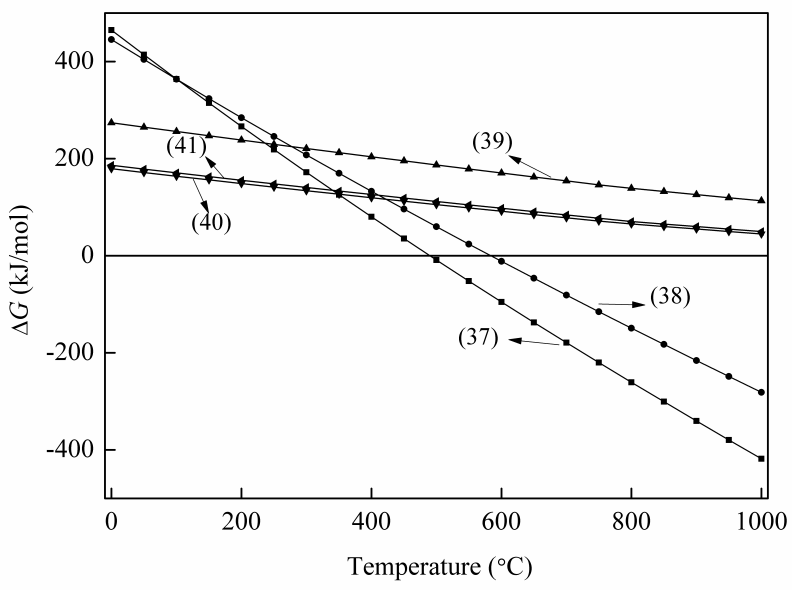

Fig. 5 Graph of relation between $\triangle \mathrm{G}$ and temperature of the products evaporation at atmospheric pressure

\section{Conclusions}

From the above analysis, the recovery of indium from LCDs via chlorinated volatile process is feasible when the chlorination temperature is between $134.49{ }^{\circ} \mathrm{C}$ and $554.25{ }^{\circ} \mathrm{C}$, and the evaporation temperature is controlled higher than $490{ }^{\circ} \mathrm{C}$, and simultaneously, the oxygen partial pressure controlled or the process explored under anaerobic conditions. At the aforementioned conditions, the influences of contents of LCDs, such as $\mathrm{SiO}_{2}, \mathrm{Al}_{2} \mathrm{O}_{3}, \mathrm{Fe}_{2} \mathrm{O}_{3}$, etc., can be neglected or avoided, except that the components of $\mathrm{CaO}, \mathrm{K}_{2} \mathrm{O}$ and $\mathrm{Na}_{2} \mathrm{O}$ contained in LCDs would consume partial pressure of $\mathrm{HCl}$ gas from PVC pyrolysis, resulting to the reduction of the indium extraction reaction rate. The present study might provide the theoretical basis for indium recovery from waste LCDs via chloride volatilization process.

\section{Conflict of interest}

The authors declare that they have no conflict of interest.

\section{Acknowledgements}

We gratefully appreciate the financial support from Natural Science Foundation of China (51678353), Shanghai "Chenguang" Program (15CG60), Shanghai Sailing Program (18YF1429900, 15YF1404300), Cultivate discipline fund of Shanghai Polytechnic University (XXKPY1601) and Eastern Scholar Professorship Grant. The authors 
also acknowledge the Graduate Student Funding Program of Shanghai Polytechnic University (EGD17YJ0007, A01GY17F022), Shanghai Polytechnic University Leap Program (EGD18XQD24), and project supported by Shanghai Cooperative Centre for WEEE Recycling (ZF1224), and Gaoyuan Discipline of Shanghai-Environmental Science and Engineering (Resource Recycling Science and Engineering).

\section{References}

1. J. Li, X. Zeng and A. Stevels, Crit. Rev. Environ. Sci. Technol., 2015, 85, 840-860.

2. K. Zhang, Y. Wu, W. Wang, B. Li, Y. Zhang and T. Zuo, Resour. Conserv. Recy., 2015, 104, 276-290.

3. X. Zeng, F. Wang, X. Sun and J. Li, ACS Sustain. Chem. Eng., 2015. 3, 1306-1312.

4. A. Matharu and Y. Wu, Liquid crystal displays: From devices to recycling, in: R. Hester, R. Harrison, Electronic Waste Management. Royal Society of Chemistry, 2009, 180-211.

5. Y. Li, Z. Liu, Q. Li and L. Zeng, Hydrometallurgy, 2011, 105, 207-212.

6. A. C. Tolcin, USGS 2012 Minerals Yearbook: Indium. http://minerals.usgs.gov/minerals/pubs/commodity/indium/myb12012-indiu.pdf (accessed Jun. 23, 2018).

7. B. Gupta, N. Mudhar and I. Singh, Sep. Purif. Technol., 2007, 57, 294-303.

8. K. Park, W. Sato, G. Grause, T. Kameda and T. Yoshioka,
Thermochim. Acta, 2009, 493, 105-108.

9. D. Choi, S. Hong and Y. Son, Materials, 2014, 7, 7662-7669.

10. K. Inoue and S. Alam, JOM, 2015, 67, 400-405.

11. J. Li, S. Gao, H. Duan and L. Liu, Waste Manage. 2009, 29, 2033-2039.

12. R. Li, T. Yuan, W. Fan, Z. Qiu, W. Su and N. Zhong, T. Nonferr. Metal. Soc., 2014, 24, 257-262.

13. E. Ma, R. Lu and Z. Xu, Green Chem., 2012, 14, 3395-3401.

14. I. C. McNeill, L. Memetea and W. J. Cole, Polym. Degrad. Stabil. 1995, 49, 181-191.

15. K. Takahashi, A. Sasaki, G. Dodbiba, J. Sadaki, N. Sato and T. Fujita, Metall. Mater. Trans. A, 2009, 40, 891-900.

16. X. Wang, X. Lu, and S. Zhang, J. Hazard. Mater. 2013, 244-245, 342-347.

17. L. Zhang, B. Wu, Y. Chen and Z. Xu, J. Clean. Prod. 2017, 162, 141-152.

18. M. Souada, C. Louage, J. Y. Doisy, L. Meunier, A. Benderrag, B. Ouddane, S. Bellayer, N. Nuns, M. Traisnel and U. Maschke, Ultrason. Sonochem., 2018, 40, 929-936.

19. Steady growth forecast for global PVC market till 2021, Pop. Plast. Packag. 2014, 59, 71-72.

20. J. Guan, S. Wang, H. Ren, Y. Guo, H. Yuan, X. Yan, J. Guo, W. $\mathrm{Gu}, \mathrm{R} . \mathrm{Su}, \mathrm{B}$. Liang, G. Gao, Y. Zhou, J. Xu and Z. Guo, RSC Adv., 2015, 5, 102836-102843.

21. R. H. Matjie, J. R. Bunt, J. H. P. van Heerden, Miner. Eng. 2005, 18, 299-310. 